\title{
UBTF wt Allele
}

National Cancer Institute

\section{Source}

National Cancer Institute. UBTF wt Allele. NCI Thesaurus. Code C147962.

Human UBTF wild-type allele is located in the vicinity of $17 \mathrm{q} 21.31$ and is approximately 17 $\mathrm{kb}$ in length. This allele, which encodes nucleolar transcription factor 1 protein, plays a role in ribosomal RNA synthesis. Mutation of the gene is associated with childhood-onset neurodegeneration with brain atrophy (CONDBA). 